Article

\title{
Purification, Characterization and Biological Activity of Polysaccharides from Dendrobium officinale
}

\author{
Kaiwei Huang ${ }^{1,+}$, Yunrong $\mathrm{Li}^{1, \dagger}$, Shengchang Tao ${ }^{1}$, Gang Wei ${ }^{1, *}$, Yuechun Huang ${ }^{2, *}$, \\ Dongfeng Chen ${ }^{3}$ and Chengfeng $\mathrm{Wu}^{1}$
}

1 College of Chinese Materia Medica, Guangzhou University of Chinese Medicine, Guangzhou 510006, China; huangkaiweifeng@163.com (K.H.); YYLi0711025@163.com (Y.L.); Taoshengchang2013@163.com (S.T.); W18719138511@hotmail.com (C.W.)

2 The First Affiliated Hospital of Guangzhou University of Traditional Chinese Medicine, Guangzhou 510080, China

3 Department of Anatomy, Guangzhou University of Chinese Medicine, Guangzhou 510006, China; Cdf27212@21cn.com

* Correspondence: weigang021@163.com (G.W.); huangyuechun@163.com (Y.H.); Tel.: +86-20-3935-8519 (G.W.); +86-137-1113-1189 (Y.H.); Fax: +86-136-1012-6298 (G.W.)

+ These authors contributed equally to this work.

Academic Editor: Christopher W. K. Lam

Received: 22 March 2016; Accepted: 25 May 2016; Published: 30 May 2016

\begin{abstract}
Polysaccharide (DOPA) from the stem of D. officinale, as well as two fractions (DOPA-1 and DOPA-2) of it, were isolated and purified by DEAE cellulose-52 and Sephacryl S-300 chromatography, and their structural characteristics and bioactivities were investigated. The average molecular weights of DOPA-1 and DOPA-2 were $394 \mathrm{kDa}$ and $362 \mathrm{kDa}$, respectively. They were mainly composed of D-mannose, D-glucose, and had a backbone consisting of 1,4-linked $\beta$-D-Man $p$ and 1,4-linked $\beta$-D-Glc $p$ with $O$-acetyl groups. Bioactivity studies indicated that both DOPA and its purified fractions (DOPA-1 and DOPA-2) could activate splenocytes and macrophages. The D. officinale polysaccharides had stimulatory effects on splenocytes, T-lymphocytes and B-lymphocytes, promoting the cell viability and NO production of RAW 264.7 macrophages. Furthermore, DOPA, DOPA-1 and DOPA-2 were found to protect RAW 264.7 macrophages against hydrogen peroxide $\left(\mathrm{H}_{2} \mathrm{O}_{2}\right)$-induced oxidative injury by promoting cell viability, suppressing apoptosis and ameliorating oxidative lesions. These results suggested that $D$. officinale polysaccharides possessed antioxidant activity and mild immunostimulatory activity.
\end{abstract}

Keywords: Dendrobium officinale; polysaccharide; structural characterization; immunostimulatory activity; antioxidant activity

\section{Introduction}

Dendrobium officinale (D. officinale), well known as Tiepi Shihu, is a precious traditional Chinese medicine in China. It is recorded in the Chinese Pharmacopoeia [1], and mainly distributed in the South of China [2]. D. officinale is traditionally recognized by traditional Chinese medical practitioners as the best Dendrobium herb for tonic purposes, and it has been used to alleviate diabetes, obesity, rheumatoid arthritis, and many other disease [3]. Because of its broad spectrum of medical properties, it is widely used as an ingredient in pharmaceuticals, nutraceuticals and food products. Currently, over-exploitation and habitat damage have caused serious scarcity of wild resources. Therefore, it was listed on the China Plant Red Data Book in 1987 [4]. The increasing demand and the short supply of the plant led to a dramatic rise in its price. Because of its potentially significant functions and high price, more and more researchers have paid attention to the study of $D$. officinale. 
It has been reported that the main active ingredients of $D$. officinale include phenols, alkaloids, bibenzyls, terpenes, flavonoids, amino acids and polysaccharides [5-10]. Pharmacological studies have demonstrated that polysaccharides extracted from $D$. officinale possessed various biological activities, such as antioxidant, immunological, anti-tumour, hypoglycaemic activities and improvement of colonic health [11-17]. During the past 20 years, it had been found that most of the purified polysaccharides from $D$. officinale were isolated by DEAE cellulose-52 chromatography with water elution. The chemical characterization and the bioactivities of these purified polysaccharides had been studied [10,18-22]. These studies indicated that they had different structural characteristics and possessed antioxidant and immunostimulatory functions [19,21,22]. However, few studies have focused on the purified polysaccharides of $D$. officinale isolated by DEAE cellulose- 52 chromatography with $\mathrm{NaCl}$ elution. Only one study reported that DOP-2 from D. officinale was isolated by DEAE cellulose-52 chromatography with $\mathrm{NaCl}$ elution and further purified by Sephacryl S-400 chromatography. The study mainly focused on the research of bioactivities of DOP-2. The evaluation of its bioactivities showed that DOP-2 had significant immunomodulatory activity in vitro [22]. However, the structural features and structure-activity relationship remain unknown.

In the present study, DOPA was isolated from D. officinale by DEAE cellulose-52 chromatography with $\mathrm{NaCl}$ elution. DOPA was further purified by Sephacryl S-300 chromatography, and two new polysaccharides (DOPA-1 and DOPA-2) were obtained. Therefore, the aims of this study were to preliminarily characterize the structure of the polysaccharide fractions isolated from the stem of D. officinale and to evaluate the bioactivity of these fractions in vitro.

\section{Results}

\subsection{Extraction, Purification and Preliminary Characterization of DOPA Fractions}

\subsubsection{Extraction and Purification of DOPA Fractions}

The crude polysaccharides were passed through a DEAE-52 cellulose column and eluted with water, $0.1,0.3$, and $1.0 \mathrm{~mol} / \mathrm{L} \mathrm{NaCl}$ solutions, and then four fractions were obtained. Two main fractions, DOPW (eluted with distilled water) and DOPA (eluted with $0.1 \mathrm{M} \mathrm{NaCl}$ solution, tubes 66-111) were collected. Evaluation of the polysaccharides' bioactivities showed that both DOPW and DOPA had excellent bioactivities. Until now, there have been few reports about the characterization of polysaccharides from $\mathrm{NaCl}$ elution and their potential activities. Thus, DOPA was further purified by Sephacryl S-300 chromatography to get more homogeneous polysaccharides. It was eluted with a $0.2 \mathrm{~mol} / \mathrm{L} \mathrm{NaCl}$ solution to obtain two polysaccharide fractions named DOPA-1 (tubes 23-50) and DOPA-2 (tubes 60-97), according to their molecular size (Figure 1). The yields of DOPA-1 and DOPA-2 from the crude D. officinale polysaccharides DOPA were $21 \%$ and $15 \%$, respectively.

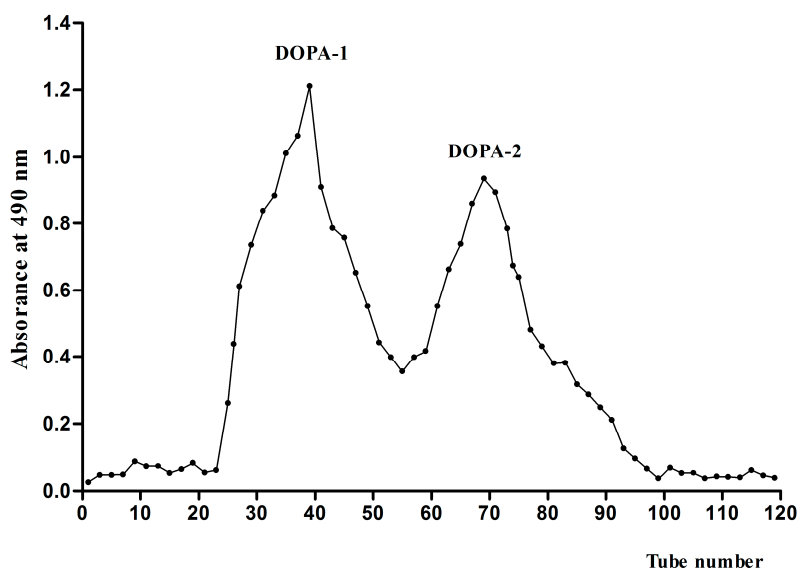

Figure 1. Elution profile of DOPA on a Sephacryl S-300 gel-permeation chromatography column. 


\subsubsection{Molecular Weight and Chemical Composition of DOPA Fractions}

HPGPC was employed to determine the molecular weights of DOPA-1 and DOPA-2 (Figure S1). As shown in Table 1, the average molecular weights of DOPA-1 and DOPA-2 were determined to be $394 \mathrm{kDa}$ and $362 \mathrm{kDa}$, respectively.

Table 1. Contents of carbohydrate and monosaccharide compositions for polysaccharide fractions from D. officinale.

\begin{tabular}{lcccc}
\hline \multirow{2}{*}{ Sample } & Carbohydrate (\%) & \multicolumn{2}{c}{ Molecular Weight (kDa) } & \multicolumn{2}{c}{ Monosaccharide Composition (Molar Ratio) } \\
\cline { 4 - 5 } & & & D-Mannose & D-Glucose \\
\hline DOPA-1 & $93.80 \%$ & 394 & 5.8 & 1 \\
DOPA-2 & $91.60 \%$ & 362 & 4.5 & 1 \\
\hline
\end{tabular}

The monosaccharide composition of the two fractions was determined using HPLC. The results (Table 1) indicated that these two fractions had the same monosaccharide composition, and the main sugar constituents of these two polysaccharide fractions were D-mannose and D-glucose. DOPA-1 was mainly composed of D-mannose, D-glucose in the molar ratio of 5.8:1, respectively. DOPA-2 was chiefly composed of D-mannose, D-glucose in the molar ratio of 4.5:1.

\subsubsection{Analysis of FT-IR Spectra of DOPA Fractions}

FT-IR spectroscopy is typically used for the qualitative measurement of organic functional groups [23-25]. The FT-IR spectra of DOPA-1 and DOPA-2 are shown in Figure 2. The strong and broad absorption peaks at $3414 \mathrm{~cm}^{-1}$ and $3395 \mathrm{~cm}^{-1}$ were characteristic of $O-\mathrm{H}$ groups. The peaks at 2924, 2891, and $2929 \mathrm{~cm}^{-1}$ were indicative of weak $\mathrm{C}-\mathrm{H}$ bond stretching vibrations. The peaks at 1734 and $1731 \mathrm{~cm}^{-1}$ were ascribed to valence vibration of $\mathrm{C}=\mathrm{O}$ of $\mathrm{O}$-acetyl groups. In addition, the absorption peaks at approximately 1377 and $1378 \mathrm{~cm}^{-1}$ could be ascribed to symmetric C-H bending vibration of the methyl groups, respectively, and the peaks at 1250 and $1251 \mathrm{~cm}^{-1}$ were assigned to the variable angle vibration ofthe $\mathrm{C}-\mathrm{O}$ vibration of $\mathrm{O}$-acetyl groups [26]. The peaks within the range of $1000-1200 \mathrm{~cm}^{-1}$ suggested the presence of $\mathrm{C}-\mathrm{O}-\mathrm{C}$ and $\mathrm{C}-\mathrm{O}-\mathrm{H}$ bonds, indicating the presence of pyranose rings [27]. In the FT-IR spectra of DOPA-1, the peak at $1064 \mathrm{~cm}^{-1}$ was due to the vibration of $\mathrm{C}-\mathrm{O}$ at the $\mathrm{C}-4$ position of a glucose residue. The peaks at $897 \mathrm{~cm}^{-1}$ were thought to be characteristic of $\beta$-anomeric carbon, indicating that the two fractions mainly contained $\beta$-type glycosidic linkages [28,29]. The peaks at 877 and $812 \mathrm{~cm}^{-1}$ were attributed to D-glucose and D-mannose in pyranose.

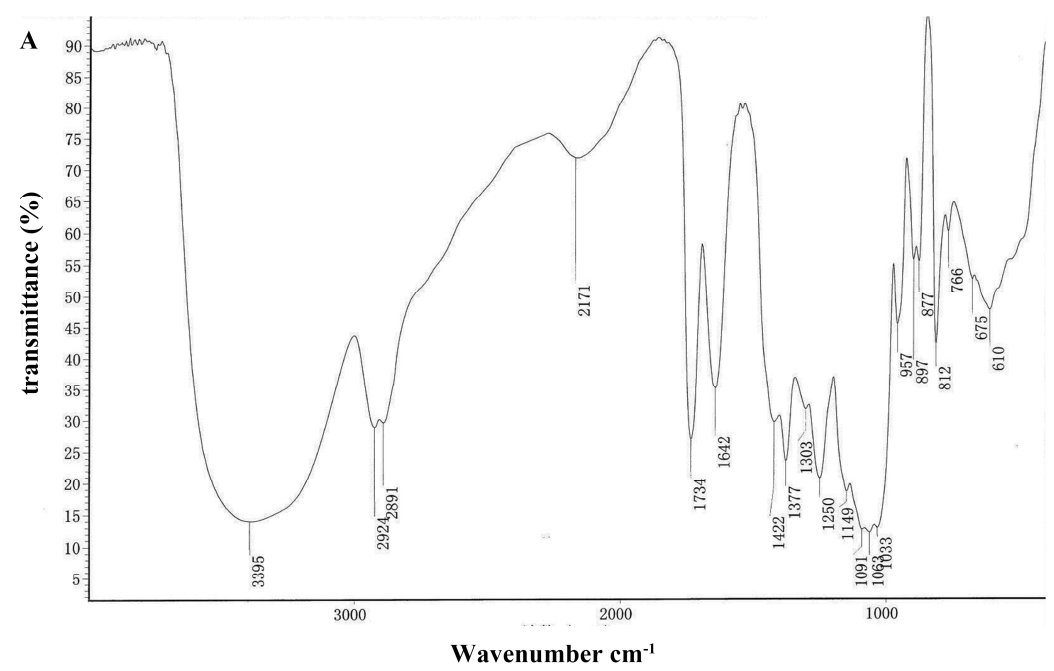

Figure 2. Cont. 


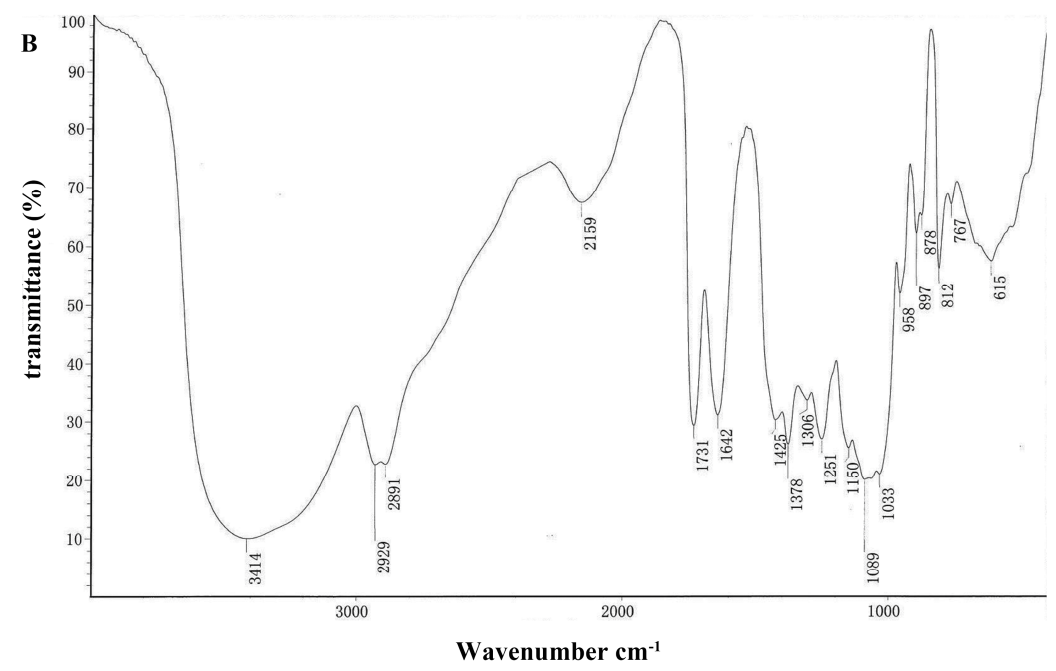

Figure 2. The FTIR spectra of DOPA-1 (A) and DOPA-2 (B).

\subsubsection{Methylation and GC-MS Analysis}

The glycosidic linkages of polysaccharides were determined by methylation and GC-MS analysis. According to the analysis of PMAA, the individual peaks were identified and the linkage patterns of DOPA-1 and DOPA-2 are shown in Table 2. Both of them had similar linkage patterns, mainly 1,4-linked Man $p$ and 1,4-linked Glc $p$. Meanwhile, a small number of terminal groups (T-Man $p$ ), 1,3,4-linked Manp, 1,2,4-linked Manp, 1,4,6-linked Man $p$ and 1,4,6-linked Glc $p$ residues were found in DOPA-1 and DOPA-2. However, the results indicated DOPA-2 had a small amount of 1,6-linked Man $p$ and 1,3,4-linked Glc $p$, which were not detected in DOPA-1. It suggested that DOPA-1 and DOPA-2 were linear glucomannans.

Table 2. Methylation analysis and of DOPA-1 and DOPA-2.

\begin{tabular}{|c|c|c|c|c|}
\hline \multirow{2}{*}{ Retention Time (min) } & \multirow{2}{*}{ Linkage Pattern } & \multirow{2}{*}{ Major Mass Fragments $(\mathrm{m} / \mathrm{z})$} & \multicolumn{2}{|c|}{ Peak Area Percentage ( $\%)$} \\
\hline & & & DOPA-1 & DOPA-2 \\
\hline 10.69 & T-Man $p$ & $102,117,129,145,161,205$ & 4.08 & 2.43 \\
\hline 12.44 & 1,4-linked Man $p$ & $101,113,117,129,131,143,161,173,233$ & 79.63 & 78.49 \\
\hline 12.53 & 1,4-linked Glcp & $101,113,117,129,131,143,161,173,233$ & 14.39 & 16.99 \\
\hline 12.73 & 1,6-linked Man $p$ & $101,117,129,161,189,233$ & - & 0.22 \\
\hline 13.35 & 1,3,4-linked Man $p$ & $118,129,160,143,185,203,231,305$ & 0.48 & 0.35 \\
\hline 13.44 & 1,3,4-linked Glc $p$ & $118,129,160,143,185,203,231,305$ & - & 0.15 \\
\hline 13.71 & 1,2,4-linked Man $p$ & $113,130,143,172,190,231$ & 0.51 & 0.57 \\
\hline 14.05 & 1,4,6-linked Man $p$ & $101,117,127,142,159,201,261$ & 0.47 & 0.37 \\
\hline 14.14 & 1,4,6-linked Glcp & $101,117,127,142,159,201,261$ & 0.44 & 0.43 \\
\hline
\end{tabular}

\subsubsection{Analysis of the NMR Spectra of DOPA Fractions}

The spectra of the two purified polysaccharide fractions showed very similar signals with slight variations in peak intensity, and the signals in the spectra were weak and not well separated (Figure 3), which may be caused by the relatively high viscosities of the $\mathrm{D}_{2}$ O solutions of DOPA- 1 and DOPA-2 [26]. When comparing these chemical shifts with previously reported NMR data on similar monosaccharide compositions $[10,26,30-36]$, the highest field signal at $\delta 2.05-2.20$ belonged to the methyl group of $\mathrm{O}$-acetyl groups in the ${ }^{1} \mathrm{H}-\mathrm{NMR}$ spectra of DOPA- 1 and DOPA-2. The methyl group and ketone of the $O$-acetyl groups were detected at signals $\delta 20.3-21.0$ and $\delta 172.9-173.9$ in the ${ }^{13} \mathrm{C}-\mathrm{NMR}$, respectively. The signals for the anomeric carbon at $\delta 100.1$, and $\delta 102.4$ were attributed to the $C-1$ atoms of 1,4-linked $\beta$-D-Man $p$ and 1,4-linked $\beta$-D-Glcp. The signals from $\delta 60.43$ to 80.26 were attributed to C-2-C-6 of the residues. 

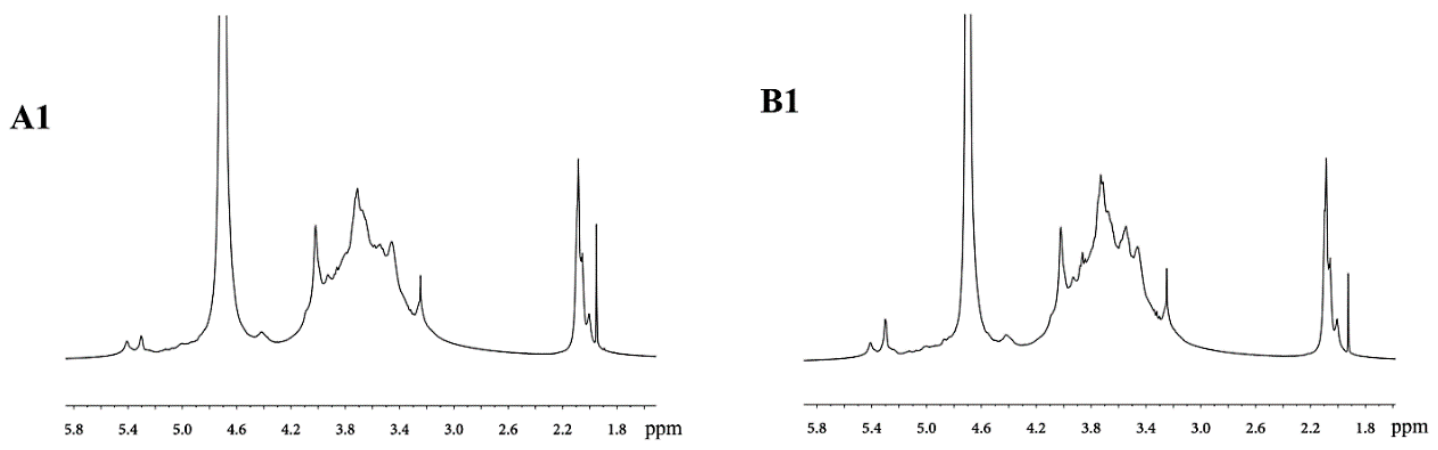

A2

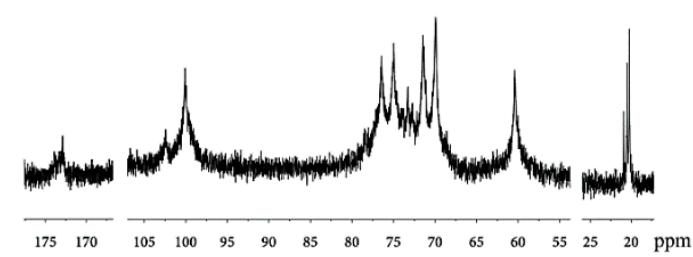

B2

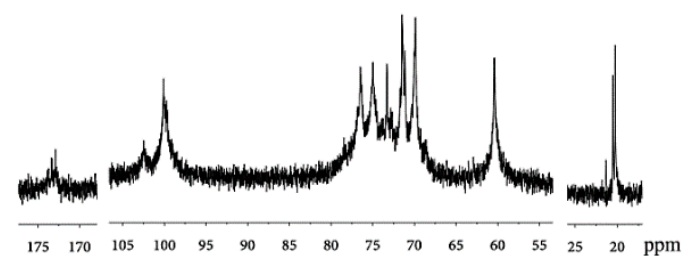

Figure 3. ${ }^{1} \mathrm{H}$ - and ${ }^{13} \mathrm{C}-\mathrm{NMR}$ spectra of DOPA-1(A1, A2) and DOPA-2 (B1, B2).

The combination of the methylation analysis and NMR spectra demonstrated that both DOPA-1 and DOPA-2 were glucomannans with $O$-acetyl groups and had a backbone consisting of 1,4-linked $\beta$-D-Man $p$ and 1,4-linked $\beta$-D-Glcp.

\subsection{Activation of RAW 264.7 Macrophages by D. officinale Polysaccharides in Vitro}

\subsubsection{Effect of D. officinale Polysaccharides on Macrophages Viability}

The cells treated with medium only had a circular morphology and a few extending pseudopodia. When RAW 264.7 cells were cultured with LPS, morphological changes were observed. Most of the cells had polygonal shapes, and the cells were larger in size than normal cells. The cells treated with D. officinale polysaccharides shared similarities with the cells treated with LPS in cellular morphology. The results indicated that the RAW 264.7 cells were stimulated after incubation with the polysaccharides from D. officinale.

The stimulatory effect of $D$. officinale polysaccharides on RAW 264.7 cells was measured by MTT assay and it is shown in Figure 4. Compared with the blank control, LPS, DOPA-1 $(50 \mu \mathrm{g} / \mathrm{mL})$, DOPA-2 $(12.5-100 \mu \mathrm{g} / \mathrm{mL})$ and DOPA $(25-100 \mu \mathrm{g} / \mathrm{mL})$ exerted a significant stimulatory effect on macrophages $(p<0.05)$. MTT is an indicator of cell metabolic activity, and are suitable for analyzing proliferation and viability, and activated macrophages produce more formazan product than non-activated macrophages [37], which suggested the D. officinale polysaccharides might promote the viability of macrophages rather than proliferation. Although DOPA $(12.5-100 \mu \mathrm{g} / \mathrm{mL})$ and DOPA-2 $(25-100 \mu \mathrm{g} / \mathrm{mL})$ promoted RAW 264.7 cells viability with statistical significance, the polysaccharides just slightly enhanced cell viability in essence. Furthermore, the cell viability decreased at high concentrations $(200 \mu \mathrm{g} / \mathrm{mL})$. Similarly, DOPA-1 mildly promoted cell viability at a dose of $50 \mu \mathrm{g} / \mathrm{mL}$, but inhibited cell viability at high concentrations $(200 \mu \mathrm{g} / \mathrm{mL})$. The other concentrations $(6.25,12.5,25$ and $100 \mu \mathrm{g} / \mathrm{mL}$ ) did not have a stimulatory effect. Thus, the concentrations $6.25-50 \mu \mathrm{g} / \mathrm{mL}$ were used in the following assay in the macrophage model. 


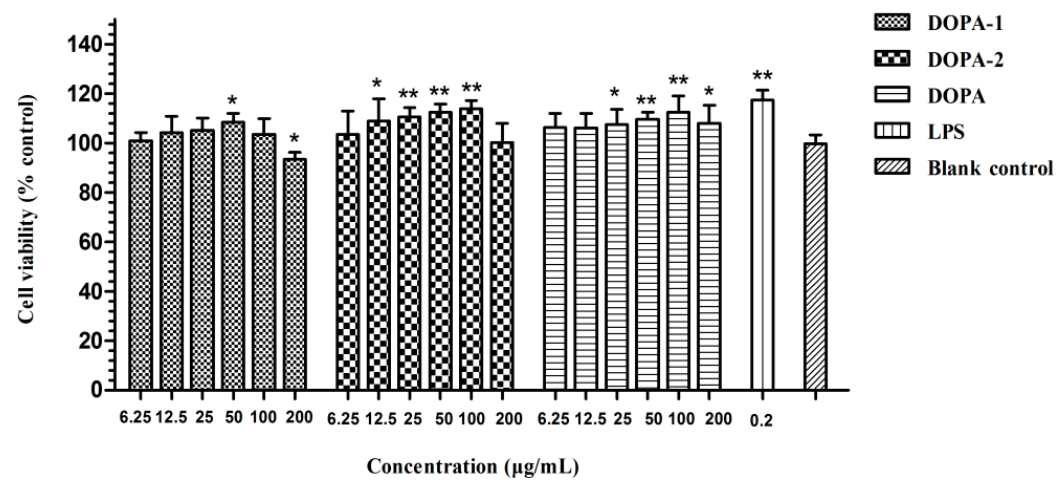

Figure 4. Effects of D. officinale polysaccharides on RAW 264.7 cell viability. The results were shown as means $\pm \mathrm{SD}(n=5) .{ }^{*} p<0.05,{ }^{* *} p<0.01$ compared with the blank control.

\subsubsection{Effects of D. officinale Polysaccharides on NO Production in Macrophages}

The Griess test was utilized to evaluate the effects of the polysaccharides on the NO production in RAW 264.7 macrophages. As shown in Table 3, compared with the blank control, LPS significantly $(p<0.05)$ promoted NO production in macrophages. Furthermore, the polysaccharides of D. officinale increased the NO production in RAW 264.7 cells in a dose- and time-dependent manner, which was significantly $(p<0.05)$ different from the blank control group. In addition, NO production was detectable at a concentration of $50 \mu \mathrm{g} / \mathrm{mL}$ after $12 \mathrm{~h}$ of stimulation, which suggested that $D$. officinale polysaccharides could quickly activate macrophages. Compared with the blank control and the positive control, D. officinale polysaccharides still stimulated NO production at $36 \mathrm{~h}$ and $48 \mathrm{~h}$, suggesting that the polysaccharides could maintain immunostimulatory activity for an extended period.

Table 3. Effects of D. officinale polysaccharides on the production of NO in RAW 264.7 cells.

\begin{tabular}{|c|c|c|c|c|c|c|}
\hline \multirow{8}{*}{$\mathbf{A}$} & \multirow{2}{*}{$\begin{array}{c}\text { Concentration } \\
(\mu \mathrm{g} / \mathrm{mL})\end{array}$} & \multicolumn{5}{|c|}{ NO Production $(\mu \mathrm{M})$} \\
\hline & & Blank Control & LPS & DOPA-1 & DOPA-2 & DOPA \\
\hline & 0 & $2.38 \pm 0.53$ & & & & \\
\hline & 0.2 & & $20.28 \pm 0.38^{* *}$ & & & \\
\hline & 6.25 & & & $3.59 \pm 0.33^{*}$ & $4.12 \pm 0.57^{* *}$ & $3.42 \pm 0.36^{*}$ \\
\hline & 12.5 & & & $4.58 \pm 0.74 * *$ & $4.86 \pm 0.42 * *$ & $3.60 \pm 0.73 * *$ \\
\hline & 25 & & & $5.11 \pm 0.52 * *$ & $5.17 \pm 0.54^{* *}$ & $3.89 \pm 0.77^{* *}$ \\
\hline & 50 & & & $6.89 \pm 0.48^{* *}$ & $7.43 \pm 0.52^{* *}$ & $5.24 \pm 0.78^{* *}$ \\
\hline \multirow{6}{*}{ B } & \multicolumn{6}{|c|}{ NO Production $(\mu \mathrm{M})$} \\
\hline & & Blank Control & LPS & DOPA-1 & DOPA-2 & DOPA \\
\hline & 12 & $1.77 \pm 0.04$ & $3.59 \pm 0.15^{* *}$ & $2.75 \pm 0.15^{* *}$ & $2.98 \pm 0.09^{* *}$ & $1.75 \pm 0.05$ \\
\hline & 24 & $1.70 \pm 0.58$ & $13.11 \pm 1.53^{* *}$ & $3.29 \pm 0.46^{*}$ & $3.45 \pm 0.34^{* *}$ & $2.25 \pm 0.47$ \\
\hline & 36 & $1.94 \pm 0.42$ & $19.53 \pm 0.43^{* *}$ & $4.23 \pm 0.65^{* *}$ & $4.53 \pm 0.73^{* *}$ & $3.26 \pm 0.46^{* *}$ \\
\hline & 48 & $2.12 \pm 0.74$ & $19.76 \pm 0.45^{* *}$ & $6.13 \pm 0.61^{* *}$ & $7.08 \pm 0.67^{* *}$ & $4.97 \pm 0.31$ ** \\
\hline
\end{tabular}

(A) The cells were treated with D. officinale polysaccharides $(6.25-50 \mu \mathrm{g} / \mathrm{mL})$ or LPS $(0.2 \mu \mathrm{g} / \mathrm{mL})$ for $48 \mathrm{~h}$; (B) RAW 264.7 cells were incubated with D. officinale polysaccharides $(50 \mu \mathrm{g} / \mathrm{mL})$ or LPS $(0.2 \mu \mathrm{g} / \mathrm{mL})$ for 12 , 24,36 and $48 \mathrm{~h}$. The results were shown as means $\pm \mathrm{SD}(n=4)$. ${ }^{*} p<0.05, * * p<0.01$ compared with the blank control.

\subsection{Effects of D. officinale Polysaccharides on Activivation of Splenocytes}

The stimulatory effect of $D$. officinale polysaccharides on splenocytes was measured by MTT assay, and the results are displayed in Figure 5. Compared with the control group, DOPA, DOPA-1 and DOPA-2 $(6.25-50 \mu \mathrm{g} / \mathrm{mL})$ significantly $(p<0.01)$ stimulated splenocytes without mitogens in a dose-dependent manner. Meanwhile, they also significantly $(p<0.05)$ stimulated T-lymphocytes 
(ConA-induced splenocytes) in a dose-dependent manner ranging from 12.5 to $50 \mu \mathrm{g} / \mathrm{mL}$. In addition, the B-lymphocytes (LPS-induced splenocytes) stimulatory effect was mildly promoted by the polysaccharides, especially at the dose of $25 \mu \mathrm{g} / \mathrm{mL}$, and the stimulatory effect then decreased. MTT was used to analyse the proliferation and viability of cells. Therefore, the stimulatory effect of $D$. officinale polysaccharides on splenocytes and splenocytes with mitogens might have induced proliferation and enhanced viability of cells.
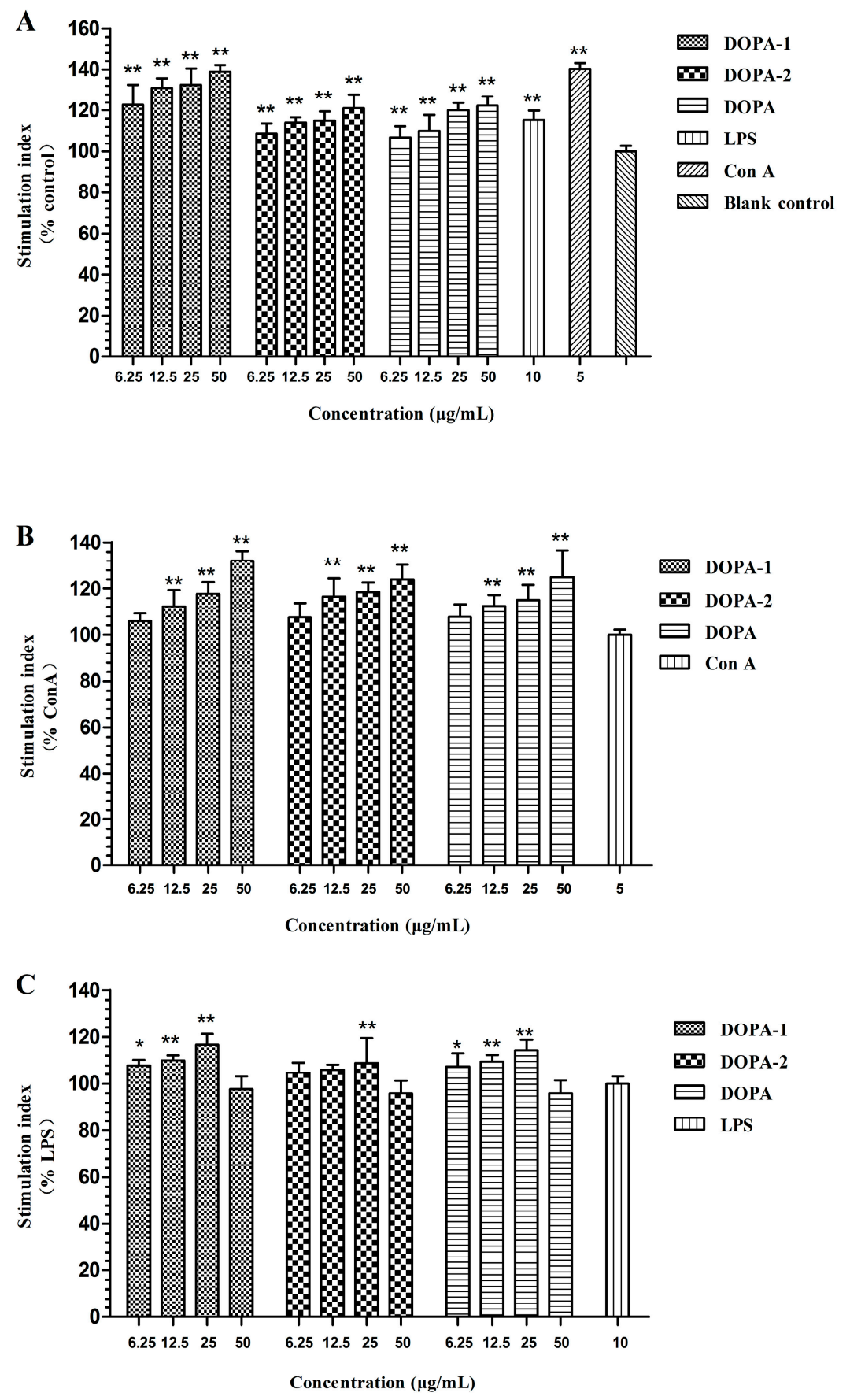

Figure 5. Stimulatory effects of DOPA-1, DOPA-2 and DOPA on the splenocytes. (A) Stimulatory effects of $D$. officinale polysaccharides on the splenocytes; (B) Stimulatory effects of $D$. officinale polysaccharides on the ConA-induced splenocytes; (C) Stimulatory effects of $D$. officinale polysaccharides on the LPS-induced splenocytes. Values were shown as means $\pm \mathrm{SD}(n=5) .{ }^{*} p<0.05,{ }^{* *} p<0.01$ compared to the control group. 
On the whole, the stimulatory effects of the polysaccharides on the splenocytes without mitogens were more noticeable than those on the splenocytes treated with ConA. The D. officinale polysaccharides had a mildly stimulatory effect on splenocytes treated with LPS. Among all the polysaccharides, DOPA-1 had the strongest promoting effects on stimulation of splenocytes. However, DOPA-2 had a weak effect.

\subsection{Antioxidant Activity Assay in Macrophages Treated with $\mathrm{H}_{2} \mathrm{O}_{2}$}

\subsubsection{Effect of $\mathrm{H}_{2} \mathrm{O}_{2}$ on the Viability of Macrophages}

After incubation with 100-1000 $\mu \mathrm{M} \mathrm{H}_{2} \mathrm{O}_{2}$ over different time intervals $(1,2$, or $3 \mathrm{~h})$, the macrophages viability was measured by an MTT assay. The RAW 264.7 cells viability decreased in a dose- and time-dependent manner. When the cells were treated with $\mathrm{H}_{2} \mathrm{O}_{2}$ at doses ranging from 100 to $1000 \mu \mathrm{M}$ for $1 \mathrm{~h}$, the cell viability did not decrease dramatically. However, when incubated with $\mathrm{H}_{2} \mathrm{O}_{2}$ for $3 \mathrm{~h}$, more than $80 \%$ of the cells were dead. As shown in Figure 6, the viability of RAW 264.7 cells treated with $500 \mu \mathrm{M} \mathrm{H}_{2} \mathrm{O}_{2}$ for $2 \mathrm{~h}$ was $53.85 \%$. According to these results, RAW 264.7 cells treated with $500 \mu \mathrm{M} \mathrm{H}_{2} \mathrm{O}_{2}$ for $2 \mathrm{~h}$ served as the control in the remaining studies.
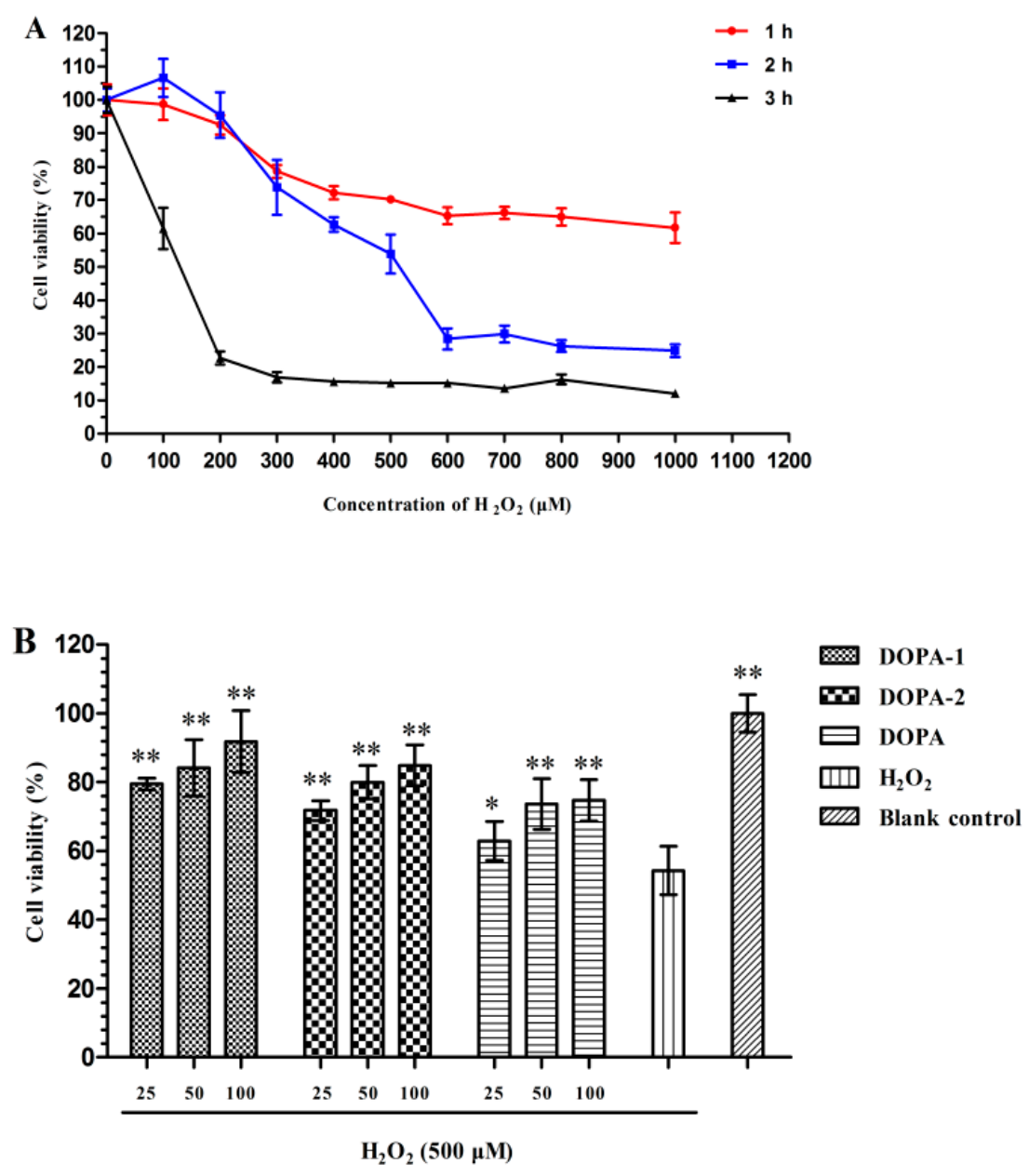

Figure 6. (A) Effects of $\mathrm{H}_{2} \mathrm{O}_{2}$ on the RAW 264.7 cells viability with various concentration of $\mathrm{H}_{2} \mathrm{O}_{2}$ for different times; (B) Effects of D. officinale polysaccharides on viability of $\mathrm{H}_{2} \mathrm{O}_{2}$-treated RAW 264.7 cells. Values were shown as means $\pm \mathrm{SD}(n=5)$. ${ }^{*} p<0.05$, ${ }^{* *} p<0.01$ compared to the $\mathrm{H}_{2} \mathrm{O}_{2}$-treated group. 


\subsubsection{Effects of D. officinale Polysaccharides on the Viability of $\mathrm{H}_{2} \mathrm{O}_{2}$-Treated Macrophages}

The present study was designed to investigate whether DOPA and its fractions (DOPA-1 and DOPA-2) could exert a cytoprotective effect on macrophages treated with $\mathrm{H}_{2} \mathrm{O}_{2}$. The effects of the polysaccharides on the viability of $\mathrm{H}_{2} \mathrm{O}_{2}$-treated macrophages were analysed by an MTT assay. The cell viability decreased markedly $(p<0.05)$ after exposure to $\mathrm{H}_{2} \mathrm{O}_{2}$. The results, shown in Figure 6, revealed that pretreatment with DOPA, DOPA-1 and DOPA-2 $(25-100 \mu \mathrm{g} / \mathrm{mL})$ markedly $(p<0.05)$ promoted cell viability compared with model group. These results suggested that DOPA, DOPA-1 and DOPA-2 could protect RAW 264.7 macrophages against $\mathrm{H}_{2} \mathrm{O}_{2}$-induced injury.

\subsubsection{Effects of D. officinale Polysaccharides on The morphology of $\mathrm{H}_{2} \mathrm{O}_{2}$-Treated Macrophages}

The morphological alteration of macrophages was observed by phase-contrast microscopy. As showed in Figure 7, RAW 264.7 cells of the blank control group retained the typical macrophage-like morphology (mentioned in Section 2.2.1). RAW 264.7 cells incubated only with $500 \mu \mathrm{M} \mathrm{H} \mathrm{H}_{2} \mathrm{O}_{2}$ for 2 $\mathrm{h}$ displayed cell shrinkage, a round shape, a granuliform surface, and a large amount of cell debris. In contrast, cells pretreated with DOPA, DOPA-1 and DOPA-2 $(100 \mu \mathrm{g} / \mathrm{mL})$ for $24 \mathrm{~h}$ prior to incubation with $\mathrm{H}_{2} \mathrm{O}_{2}$ maintained their morphology better than the model group, showing polygonal shapes and some extending pseudopodia.

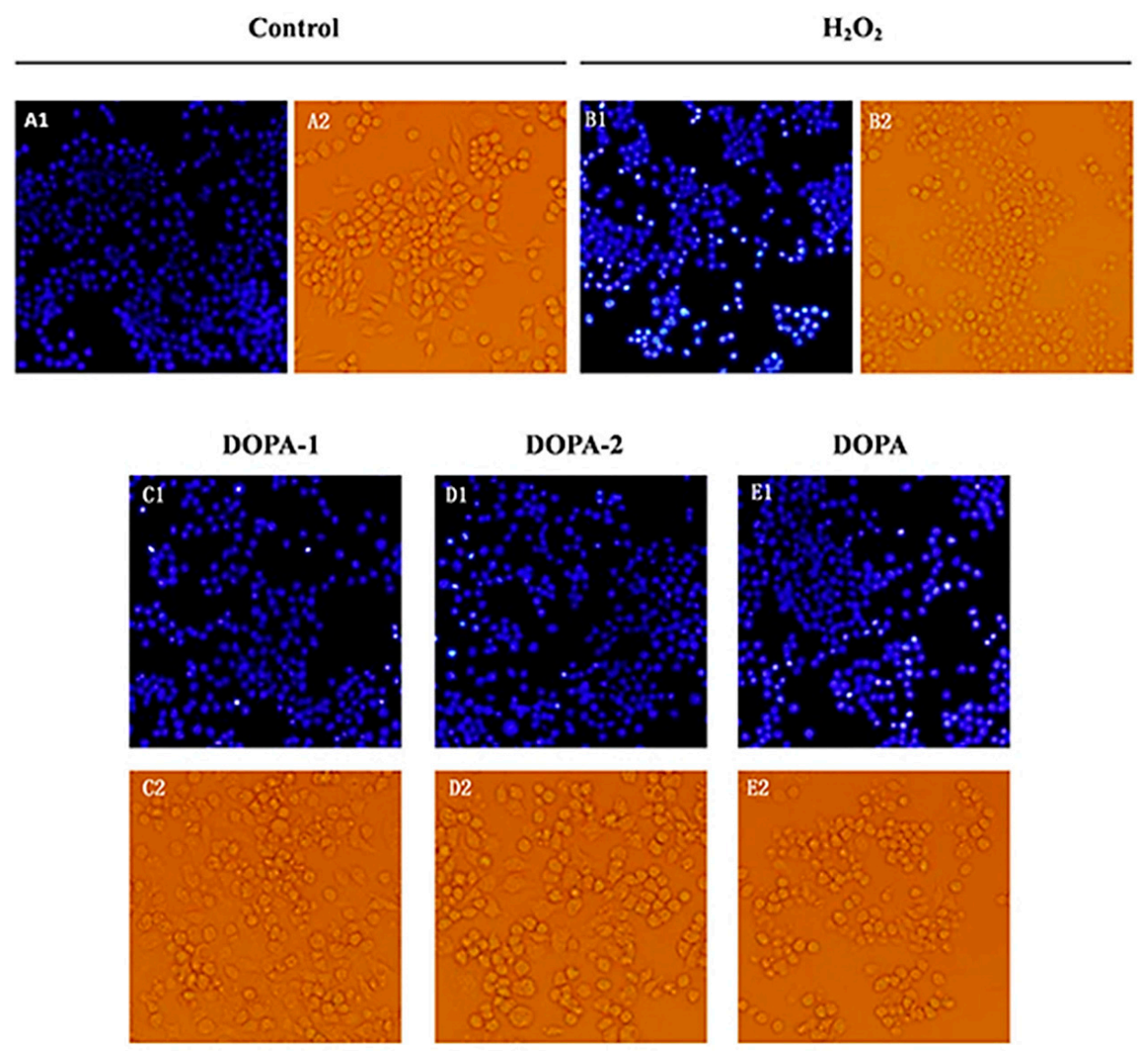

Figure 7. Effects of D. officinale polysaccharides on cell morphology of RAW 264.7 cells treated with $\mathrm{H}_{2} \mathrm{O}_{2}$. (1) Morphological changes of RAW 264.7 cells were observed by fluorescence microscope after staining with Hoechst 33258. (2) Morphological changes of RAW 264.7 cells were observed by phase-contrasted microscopy. (A1/A2) Cells treated with medium alone; (B1/B2) cells treated with $\mathrm{H}_{2} \mathrm{O}_{2}$ alone; (C1/C2) cells pretreated with DOPA-1 (100 $\left.\mu \mathrm{g} / \mathrm{mL}\right)$ prior to exposure to $\mathrm{H}_{2} \mathrm{O}_{2} ;(\mathbf{D 1} / \mathbf{D} 2)$ cells pretreated with DOPA-2 $(100 \mu \mathrm{g} / \mathrm{mL})$ prior to exposure to $\mathrm{H}_{2} \mathrm{O}_{2} ;($ E1/E2) cells pretreated with DOPA $(100 \mu \mathrm{g} / \mathrm{mL})$ prior to exposure to $\mathrm{H}_{2} \mathrm{O}_{2}$. 
The DNA fluorescent dye Hoechst 33258 was used to further investigate the effects of D. officinale polysaccharides on the DNA and nuclear structure of RAW 264.7 cells treated with $\mathrm{H}_{2} \mathrm{O}_{2}$. As shown in Figure 7, cells treated with $\mathrm{H}_{2} \mathrm{O}_{2}$ alone had condensed chromatin or nuclear fragmentation and small bright, condensed dots known as apoptotic bodies, which are the biochemical indicator of apoptosis. The nuclei of the blank control were regular, with no observable condensation. In addition, pretreatment with DOPA, DOPA-1 and DOPA-2 $(100 \mu \mathrm{g} / \mathrm{mL})$ significantly decreased this nuclear condensation and fragmentation. The results indicated that $D$. officinale polysaccharides had a protective effect against $\mathrm{H}_{2} \mathrm{O}_{2}$-induced apoptosis in macrophages.

\section{Discussion}

Macrophages are the first line of defence in the host defence response after the epithelial barrier, and play an important role in innate and adaptive immune response [38,39]. Activated macrophages can kill pathogenic microorganisms, inhibit tumour growth and cancer metastasis, and clear apoptotic and mutant cells through phagocytosis and the secretion of inflammatory mediators, including cytokines, chemokines and NO $[40,41]$. Our results demonstrated that the polysaccharides of D. officinale can promote the cell viability and NO production of RAW 264.7 macrophages. Cellular and humoral immunity are an important part of immune response, characterized by $\mathrm{T}$ cells and $\mathrm{B}$ cells, respectively, which plays an important role in host defence. LPS and ConA are mitogens for B-lymphocytes and T-lymphocytes, respectively. Spleen lymphocytes induced by ConA or LPS have been used to evaluate T- or B-lymphocyte activity [42,43]. The results indicated that D. officinale polysaccharides could stimulate splenocytes with or without mitogen stimulation (ConA or LPS). The results demonstrated that the RAW 264.7 macrophages and splenocytes could be stimulated by the polysaccharides of $D$. officinale. On the whole, the $D$. officinale polysaccharides could promote the activity of immunocytes with statistical significance, but exerted weak effects in some indexes essentially. For example, the officinale polysaccharides did not promote the cell viability and NO production of macrophages, and the activity of B-lymphocytes by a large margin. The results suggested that the polysaccharides of $D$. officinale had mild immunostimulatory activity.

$\mathrm{H}_{2} \mathrm{O}_{2}$ is an important member of the reactive oxygen species (ROS) family [44]. It can be decomposed into a hydroxyl radical and oxygen radical to induce oxidative damage. Furthermore, $\mathrm{H}_{2} \mathrm{O}_{2}$ can cause prolonged damage, even after being scavenged [45-47]. Thus, $\mathrm{H}_{2} \mathrm{O}_{2}$ is a common inducer in oxidative stress cell models. Macrophages are the main targets for action of pro-oxidants. Many studies have indicated that the virulence of some bacteria triggers the death of activated macrophages by the stimulation of ROS production [48,49]. Therefore, $\mathrm{H}_{2} \mathrm{O}_{2}$-treated macrophages were employed in this study to examine the antioxidant activity of $D$. officinale polysaccharides. The preliminary experiments demonstrated that $D$. officinale polysaccharides significantly promoted the viability of RAW 264.7 cells induced by $\mathrm{H}_{2} \mathrm{O}_{2}$. In addition, the pretreatment with $D$. officinale polysaccharides significantly decreased the apoptosis induced by $\mathrm{H}_{2} \mathrm{O}_{2}$ and protected cell morphology and structure from $\mathrm{H}_{2} \mathrm{O}_{2}$-treated oxidative lesions. Based on the observed viability and morphology, our findings indicated that $D$. officinale polysaccharides could effectively attenuate $\mathrm{H}_{2} \mathrm{O}_{2}$-incuded cell lesions.

The bioactivity of polysaccharides is related to their molecular weight, chemical composition, glycosidic linkage, conformation, degree of branching and so on [50]. The results showed that the purified polysaccharide fractions, which had molecular weights of 394 and $362 \mathrm{kDa}$, exerted mildly immunostimulatory activity and protective effects against oxidative injury. These findings were in agreement with other reports indicating that polysaccharides with molecular weights larger than $100 \mathrm{kDa}$ have excellent bioactivity. Molecular weights of the acidic polysaccharides are positively correlated to their bioactivities [51-53]. Notably, DOPA-1 and DOPA-2 had high mannose content. Some studies have shown that high mannose content has a positive influence on their bioactivities [54]. Both DOPA-1 and DOPA-2 contained 1,4-linked $\beta$-D-Man $p$ and O-acetyl groups. The structural features of 1,4-linked $\beta$-D-Man $p$ and $O$-acetyl groups exist in the polysaccharides of many medicinal 
Dendrobium species, such as Dendrobium officinale, Dendrobium huoshanense, Dendrobium nobile Lindl, and Dendrobium tosaense $[10,26,32,36,55]$. In addition, the polysaccharides showed excellent bioactivities. Therefore, the 1,4-linked $\beta$-D-Man $p$ and $O$-acetyl groups are likely the main structural features contributing to the bioactivities of polysaccharides. D. officinale is traditionally recognized by traditional Chinese medical practitioners as the best herb among the medicinal Dendrobium species. Therefore, some special structural features in D. officinale may remain unexplored. In addition, although DOPA-1 and DOPA-2 were similar in their structural characteristics, they had different effects on biological activities. For example, DOPA-2 exerted a weak effect on splenocytes. The difference was most likely due to differences in other specific structural characteristics. Therefore, a detailed study on the structural features and mechanisms responsible for their bioactivities must be carried out to fully reveal the structure-activity relationship of $D$. officinale polysaccharides.

\section{Materials and Methods}

\subsection{Materials and Reagents}

D. officinale was collected from the Zhejiang Province in China. The botanical origin of plants was identified by Pro. Gang Wei. The murine macrophage cell line RAW 264.7 was obtained from the cell bank of the Chinese Academy of Science (Shanghai, China). DEAE cellulose-52 was purchased from Yuanye Biological Technology Co. (Shanghai, China), and Sephacryl S-300 was purchased from GE HealthCare Biosciences AB (Uppsala, Sweden). 3-(4,5-dimethylthiazol-2-yl)-2,5-diphenyltetrazolium bromide (MTT), lipopolysaccharide (LPS, from Escherichia coli serotype O111:B4), and concanavalin A (ConA, Type IV) were purchased from Sigma-Aldrich (St. Louis, MO, USA). The nitric oxide (NO) assay kit and the Hoechst staining kit were purchased from Beyotime Biotechnology (Jiangsu, China). All other reagents were of analytical grade.

\subsection{Extraction and Isolation of Polysaccharides}

\subsubsection{Extraction Procedures}

The fresh stems of $D$. officinale were pulverized into powder in a high-speed disintegrator. To remove lipids, pigments and small molecule materials, the powder was extracted with $80 \%$ ethanol and petroleum ether successively. The residue was then extracted thrice with water. The filtrate was pooled and concentrated. Then, the concentrated solution was precipitated by adding anhydrous ethanol to a final concentration of $80 \%(v / v)$ and kept overnight at $4{ }^{\circ} \mathrm{C}$. Next, the precipitate was dissolved in distilled water and deproteinized by the Sevag method [56]. The solution was precipitated with anhydrous ethanol and then centrifuged. After centrifugation, the precipitate was washed with anhydrous ethanol and petroleum ether in turn and then lyophilized. The crude polysaccharides were stored at $4{ }^{\circ} \mathrm{C}$ for further analyses and experiments.

\subsubsection{Isolation and Purification of the Polysaccharides}

The crude polysaccharides were sequentially purified using DEAE cellulose-52 and Sephacryl S-300 chromatography as previously described, with slight modifications [22,53]. The crude polysaccharides were dissolved in distilled water and loaded onto an anion exchange column of DEAE cellulose-52 (pre-equilibrated with deionized water). The column was eluted with water, 0.1 , 0.3 , and $1.0 \mathrm{~mol} / \mathrm{L} \mathrm{NaCl}$ solutions at a flow rate of $1 \mathrm{~mL} / \mathrm{min}$. The carbohydrate content in each fraction was determined by the phenol-sulfuric acid method, and glucose was used as the standard. The fraction eluted by $0.1 \mathrm{~mol} / \mathrm{L} \mathrm{NaCl}$ solution (named DOPA) was collected, dialyzed and lyophilized. DOPA was further purified using Sephacryl S-300 chromatography and eluted with a $0.2 \mathrm{~mol} / \mathrm{L} \mathrm{NaCl}$ solution to separate two fractions (DOPA-1 and DOPA-2). The related fractions were collected, dialyzed, and lyophilized for further study. 


\subsection{Preliminary Characterization of DOPA Fractions}

\subsubsection{Monosaccharide Composition Analysis}

The monosaccharide composition of DOPA-1 and DOPA-2 was analysed by high performance liquid chromatography (HPLC). The polysaccharide samples were hydrolysed with $2 \mathrm{M}$ trifluoroacetic acid solution (TFA). The hydrolysed samples and the monosaccharide standards were converted to their derivatives with $0.5 \mathrm{M}$ 1-phenyl-3-methyl-5-pyrazolone (PMP). The analysis was performed on a HPLC system (Shimadzu, Kyoto, Japan). The analytical column used was an XDB-C18 column $\left(4.6 \times 150 \mathrm{~mm}, 5 \mu \mathrm{m}\right.$, Agilent ZORBAX). The mobile phase was $0.05 \mathrm{M}$ aqueous $\mathrm{KH}_{2} \mathrm{PO}_{4}$ (solvent A) and acetonitrile (solvent $\mathrm{B}$ ).

\subsubsection{Molecular Weight Determination}

The relative molecular weights of the two fractions (DOPA-1 and DOPA-2) were measured by high-performance gel permeation chromatography (HPGPC). The samples and the T-series dextran standards (MW: 800, 400, 200, 100, 50, 20, 10, and $5 \mathrm{kDa}$ ) were analysed on an Agilent 1100 series HPLC system (Palo Alto, CA, USA) equipped with the RI-101SHODEX RID detector (Tosoh, Japan) using a KS-805 column and a KS-804 column (Tosoh, Japan).

\subsubsection{Fourier Transform Infrared Spectroscopy Analysis}

The infrared (IR) spectra of DOPA-1 and DOPA-2 were recorded by a Fourier transform infrared spectroscopy (FT-IR) spectrophotometer. The sample was ground into powder with spectroscopic grade potassium bromide $(\mathrm{KBr})$ powder and then pressed into pellets for FT-IR measurement in the frequency range of $4000-500 \mathrm{~cm}^{-1}$ [57].

\subsubsection{Methylation and GC-MS Analysis}

The polysaccharide fractions DOPA-1 and DOPA-2 were methylated using methyl iodide and solid sodium hydroxide in dimethyl sulfoxide according to the method reported previously [58,59]. Then, the permethylated polysaccharide samples were hydrolyzed with TFA, reduced by $\mathrm{NaBH}_{4}$, and then $O$-acetylated with pyridine-acetic anhydride as partially methylated alditol acetates (PMAA), which were further analyzed by GC-MS for linkage analysis. The GC-MS analysis was performed on an Agilent 7890A-5975C system (Agilent Technology, Santa Clara, CA, USA) with a HP-5 capillary column.

\subsubsection{Nuclear Magnetic Resonance Spectroscopy}

The ${ }^{1} \mathrm{H}-\mathrm{Nuclear}$ magnetic resonance (NMR) and ${ }^{13} \mathrm{C}-\mathrm{NMR}$ spectra were recorded using a Brucker DRX-500 NMR spectrometer. DOPA-1 and DOPA-2 were dissolved in $\mathrm{D}_{2} \mathrm{O}$ and examined at $500 \mathrm{MHz}$ at $30^{\circ} \mathrm{C}$.

\subsection{Activation of RAW 264.7 Macrophages in Vitro}

\subsubsection{Cell Culture}

The murine macrophage cell line RAW 264.7 was maintained in RPMI-1640 medium (Gibco, Grand Island, NY, USA) containing 10\% foetal bovine serum (FBS) (HyClone, Logan City, UT, USA), $100 \mathrm{\mu g} / \mathrm{mL}$ streptomycin and $100 \mathrm{U} / \mathrm{mL}$ penicillin (Solarbio Technology Co., Beijing, China) at $37^{\circ} \mathrm{C}$ under a humidified atmosphere of $5 \% \mathrm{CO}_{2}$.

\subsubsection{Cell Stimulation Assay}

The stimulation of D. officinale polysaccharides on RAW 264.7 cells was measured using an MTT assay according to a reported method with slight modifications [37]. Briefly, the RAW 264.7 cell suspension was plated in 96-well microplates $\left(1 \times 10^{5}\right.$ cells $\left./ \mathrm{mL}\right)$, incubated $12 \mathrm{~h}$ and then treated 
with serial concentrations of polysaccharides DOPA, DOPA-1, and DOPA-2 $(6.25,12.5,25,50,100$, $200 \mu \mathrm{g} / \mathrm{mL}$ ) for $24 \mathrm{~h}$. Cells treated with equal volumes of RPMI-1640 medium and LPS solution $(0.2 \mu \mathrm{g} / \mathrm{mL})$ were used as a vehicle control and a positive control. After treatment, cells were incubated with the MTT solution $(5 \mathrm{mg} / \mathrm{mL})$ for another $4 \mathrm{~h}$, and then the medium was discarded. The formazan crystals were dissolved using $100 \mu \mathrm{L}$ of dimethyl sulfoxide (DMSO). The absorbance was read at $570 \mathrm{~nm}$ on a microplate reader (Bio-Rad, Hercules, CA, USA). The stimulation index was expressed as the ratio of the absorbance values of the treatment group to values of the vehicle control group.

$$
\text { Stimulation index }=\text { OD experimental } / \mathrm{OD}_{\text {control }} \times 100 \%
$$

\subsubsection{Assay of the Nitric Oxide (NO) Production of Macrophages}

The Griess reaction was applied to evaluate the NO production of the cells [60]. RAW 264.7 cells were treated with different concentrations of DOPA, the DOPA fractions, LPS and RPMI-1640 medium, similarly to the above treatments. After incubation, the supernatant was collected and reacted with an equal volume of Griess reagent at room temperature for $15 \mathrm{~min}$. The absorbance was read at $570 \mathrm{~nm}$, and the nitrite $\left(\mathrm{NaNO}_{2}\right)$ was used as a standard.

\subsection{Activation of Splenocytes in Vitro}

The stimulation of $D$. officinale polysaccharides on splenocytes was measured using an MTT assay as described previously $[37,61,62]$. Spleens collected from male BALB/c mice were minced using surgical scissors. The spleen fragments were grinded through a stainless steel cell strainer into RPMI-1640 medium (without 10\% FBS). The cell suspension was centrifuged at $110 \times g$ for $4 \mathrm{~min}$, and then the supernatant was removed. The recovered spleen cells were resuspended in lysis buffer $\left(0.15 \mathrm{M} \mathrm{NH}_{4} \mathrm{Cl}, 0.01 \mathrm{M} \mathrm{KHCO}_{3}, 0.0001 \mathrm{M}\right.$ EDTA-2Na) to remove the erythrocytes. The cells were washed twice with phosphate-buffered saline (PBS) and resuspended in RPMI-1640 medium. The viability of the splenocytes was over $95 \%$, according to the trypan blue dye exclusion test. Cells $\left(3 \times 10^{6}\right.$ cells $\left./ \mathrm{mL}\right)$ were plated in 96-well plates and then treated with $6.25,12.5,25$, or $50 \mu \mathrm{g} / \mathrm{mL}$ polysaccharides, respectively, or with a polysaccharide $(6.25,12.5,25,50 \mu \mathrm{g} / \mathrm{mL})$ solution containing LPS $(10 \mu \mathrm{g} / \mathrm{mL})$ or ConA $(5 \mu \mathrm{g} / \mathrm{mL})$. Cells treated with RPMI-1640 medium were used as a vehicle control. After incubating for $72 \mathrm{~h}$, the MTT solution was added to each well and then further incubated for another $4 \mathrm{~h}$. Subsequently, the cell suspension was centrifuged at $309 \times g$ for $15 \mathrm{~min}$, and the medium was removed. One hundred microliters of DMSO was added to dissolve the formazan crystals. The absorbance was read at $570 \mathrm{~nm}$. The stimulation index was calculated by the following equation:

$$
\text { Stimulation index }=\text { OD experimental } / \mathrm{OD}_{\text {control }} \times 100 \%
$$

\subsection{Antioxidant Activity Assay in Macrophages Treated with $\mathrm{H}_{2} \mathrm{O}_{2}$}

\subsubsection{Assessment of Cell Viability}

The cell viability was determined using an MTT assay [44]. Briefly, RAW 264.7 cells were cultured at a density of $1 \times 10^{5}$ cells $/ \mathrm{mL}$ in 96-well plates overnight and were treated with indicated concentrations of DOPA, DOPA1 and DOPA-2 $(25,50,100 \mu \mathrm{g} / \mathrm{mL})$ for $24 \mathrm{~h}$. The cells of blank control group and model group were incubated with an equal volume of RPMI-1640 medium. After treatment, the medium was discarded. Then, all of the cells were treated with $\mathrm{H}_{2} \mathrm{O}_{2}(500 \mu \mathrm{mol} / \mathrm{L})$ for $2 \mathrm{~h}$, except the blank control cells were treated with an equal volume of RPMI-1640 medium without $\mathrm{H}_{2} \mathrm{O}_{2}$. The MTT solution was added to each well, and the plates were incubated for $4 \mathrm{~h}$ at $37^{\circ} \mathrm{C}$. The medium was discarded, and $100 \mu \mathrm{L}$ of dimethyl sulfoxide (DMSO) was added to the wells to solubilize the 
crystals. Finally, the absorbance was measured by a microplate reader at $570 \mathrm{~nm}$. The cell viability was calculated by the following equation:

$$
\text { Cell viability }(\%)=\mathrm{OD}_{\text {experimental }} / \mathrm{OD}_{\text {blank }} \text { control } \times 100 \%
$$

\subsubsection{Morphological Observation}

The morphological changes of RAW 264.7 cells were observed under a phase-contrast microscope (BX51, Olympus Optical Co. Ltd., Tokyo, Japan). RAW 264.7 cells were seeded in 12-well plates at a density of $1 \times 10^{5}$ cells $/ \mathrm{mL}$. After the pretreatment, the cells were stained with Hoechst 33258 dye staining for $30 \mathrm{~min}$ at room temperature in the dark and then observed under a fluorescence microscope (BX51, Olympus Optical Co. Ltd.).

\subsection{Statistical Analysis}

All experiments were repeated at least three times. All values are expressed as the mean \pm standard deviation (SD). Statistical significance was determined by one-way analysis of variance (ANOVA). $p<0.05$ was considered to be statistically significant. All statistical analyses were conducted using SPSS for Windows, Version 19.0 (SPSS, Chicago, IL, USA).

\section{Conclusions}

In this study, crude polysaccharides were successfully extracted from the stem of D. officinale. DOPA and two fractions (DOPA-1, DOPA-2) were isolated and purified. Their structural characteristics and bioactivities were investigated. These two polysaccharide fractions mainly comprised D-mannose and D-glucose. Their molecular weights were $394 \mathrm{kDa}$ and $362 \mathrm{kDa}$, respectively. The combination of the methylation analysis and spectra analysis (FT-IR, ${ }^{1} \mathrm{H}$ - and ${ }^{13} \mathrm{C}-\mathrm{NMR}$ ) demonstrated that both DOPA-1 and DOPA-2 were glucomannans with $O$-acetyl groups and had a backbone consisting of 1,4-linked $\beta$-D-Man $p$ and 1,4-linked $\beta$-D-Glc $p$. Furthermore, the bioactivity studies demonstrated that $D$. officinale polysaccharides could slightly promote the cell viability and NO production of RAW 264.7 macrophages, and exert stimulatory effects on splenocytes, T-lymphocytes and B-lymphocytes. In addition, $D$. officinale polysaccharides exerted significant protective effects against $\mathrm{H}_{2} \mathrm{O}_{2}$-induced oxidative injury in RAW 264.7 macrophages. Thus, the D. officinale polysaccharides possessed mild immunostimulatory activity and antioxidant activity.

Supplementary Materials: Supplementary materials can be accessed at: http://www.mdpi.com/1420-3049/21/ 6/701/s1.

Acknowledgments: The authors are grateful for supported from the Science and Technology Planning Project of Guangdong Province, China (2013B060400022), the Special Foundation of 2015 High Level University Construction (No. 2050205).

Author Contributions: Shengchang Tao and Yunrong Li completed the extraction and purification of polysaccharides, and study the structure characterization of DOPA-1 and DOPA-2. Kaiwei Huang, and Chengfeng Wu accomplished bioactivity of D. officinale polysaccharides. Dongfeng Chen prepared for the experimental materials. Gang Wei and Yuechun Huang instructed all the members to carry out the research entitled "Purification, characterization and biological activity of polysaccharides from Dendrobium officinale". All authors read and approved the final version of the manuscript.

Conflicts of Interest: The authors declared no conflict of interest.

\section{References}

1. Committee, C.P. Pharmacopoeia of China; Medical Science Press: Beijing, China, 2010; Volume I, pp. $265-266$.

2. Wu, Z., Raven, P.H., Hong, D., Eds.; Flora of China; Science Press: Beijing, China, 1999; Volume 19, p. 67.

3. Xing, X.H.; Cui, S.W.; Niec, S.P.; Phillips, G.O.; Goff, H.D.; Wang, Q. A review of isolation process, structural characteristics, and bioactivities of water-soluble polysaccharides from Dendrobium plants. Bioact. Carbohydr. Diet. Fibre 2013, 1, 131-147. [CrossRef]

4. Fu, L.G. China Plant Red Data Book: Rare and Endangered Plants; Science Press: Beijing, China, 1992; pp. $492-493$. 
5. Zhang, A.L.; Wei, T.; Si, J.P.; Jin, L.Y.; Mo, Y.N. Study on basic amino acid contents in Dendrobium officinale. J. Chin. Mater. Med. 2011, 19, 2632-2635.

6. Chen, X.M.; Wang, F.F.; Wang, Y.Q.; Li, X.L.; Wang, A.R.; Wang, C.L.; Guo, S.X. Discrimination of the rare medicinal plant Dendrobium officinale based on naringenin, bibenzyl, and polysaccharides. Sci. China Life Sci. 2012, 55, 1092-1099. [CrossRef] [PubMed]

7. Guo, X.; Li, Y.; Li, C.; Luo, H.; Wang, L.; Qian, J.; Luo, X.; Xiang, L.; Song, J.; Sun, C.; et al. Analysis of the Dendrobium officinale transcriptome reveals putative alkaloid biosynthetic genes and genetic markers. Gene 2013, 527, 131-138. [CrossRef] [PubMed]

8. Yang, L.; Wang, Z.; Xu, L. Simultaneous determination of phenols (bibenzyl, phenanthrene, and fluorenone) in dendrobium species by high-performance liquid chromatography with diode array detection. J. Chromatogr. A 2006, 1104, 230-237. [CrossRef] [PubMed]

9. Wei, Z.Y.; Lu, J.J.; Jin, C.S.; Xia, H. Chemical constituents from n-butanol extracts of Dendrobium officinale. Mod. Chin. Med. 2013, 23, 1042-1045.

10. Hua, Y.F.; Zhang, M.; Fu, C.X.; Chen, Z.H.; Chan, G.Y. Structural characterization of a 2-O-acetylglucomannan from Dendrobium officinale stem. Carbohydr. Res. 2004, 339, 2219-2224. [CrossRef] [PubMed]

11. Meng, L.Z.; Lv, G.P.; Hu, D.J.; Cheong, K.L.; Xie, J.; Zhao, J.; Li, S.P. Effects of polysaccharides from different species of Dendrobium (Shihu) on macrophage function. Molecules 2013, 18, 5779-5791. [CrossRef] [PubMed]

12. Pan, L.H.; Li, X.F.; Wang, M.N.; Zha, X.Q.; Yang, X.F.; Liu, Z.J.; Luo, Y.B.; Luo, J.P. Comparison of hypoglycemic and antioxidative effects of polysaccharides from four different Dendrobium species. Int. J. Biol. Macromol. 2014, 64, 420-427. [CrossRef] [PubMed]

13. Xiong, L.; Cao, Z.X.; Peng, C.; Li, X.H.; Xie, X.F.; Zhang, T.M.; Zhou, Q.M.; Yang, L.; Guo, L. Phenolic glucosides from Dendrobium aurantiacum var. Denneanum and their bioactivities. Molecules 2013, 18, 6153-6160. [CrossRef] [PubMed]

14. Cai, H.L.; Huang, X.J.; Nie, S.P.; Xie, M.Y.; Phillips, O.G.; Cui, S.W. Study on Dendrobium officinale O-acetyl-glucomannan (dendronan ${ }^{\circledR}$ ): Part III. Immunomodulatory activity in vitro. Bioact. Carbohydr. Diet. Fibre 2015, 5, 99-105. [CrossRef]

15. Huang, X.J.; Nie, S.P.; Cai, H.L.; Zhang, G.Y.; Cui, S.W.; Xie, M.Y.; Phillips, G.O. Study on Dendrobium officinale O-acetyl-glucomannan: Part VI. Protective effects against oxidative stress in immunosuppressed mice. Food Res. Int. 2015, 72, 168-173. [CrossRef]

16. Huang, X.J.; Nie, S.P.; Cai, H.L.; Zhang, G.Y.; Cui, S.W.; Xie, M.Y.; Phillips, G.O. Study on Dendrobium officinale O-acetyl-glucomannan (dendronan ${ }^{\circledR}$ ): Part IV. Immunomodulatory activity in vivo. J. Funct. Foods. 2015, 15, 525-532. [CrossRef]

17. Zhang, G.Y.; Nie, S.P.; Huang, X.J.; Hu, J.L.; Cui, S.W.; Xie, M.Y.; Phillips, G.O. Study on Dendrobium officinale O-acetyl-glucomannan (dendronan ${ }^{\circledR}$ ). Part VII. Improving effects on colonic health of mice. J. Agric. Food Chem. 2015, 64, 2485-2491. [CrossRef] [PubMed]

18. Yang, H.; Wang, S.C.; Wang, Z.T.; Hu, Z.B. Structure analysis of polysaccharides from Dendrobium candidum. Chin. Pharm. J. 2004, 39, 254-256.

19. Sheng, J.R. Extraction, Isolation, Purification, Structural Analysis of the Polysaccharide from Dendrobium Candidum; Guangxi Teachers Education University: Guangxi, China, 2009.

20. Wang, S.L.; Zheng, G.Z.; He, J.B.; Yu, X.J.; Wu, Y. Studies on polysaccharides of Dendrobium candidum. Acta Bot. Yunnanica 1997, 10, 389-395.

21. Bing, Y.B. Preliminary Study on Structure and Anti-Oxidation of the Polysaccharide from Dendrobium officinale; Beijing Forestry University: Beijing, China, 2014.

22. Xia, L.J.; Liu, X.F.; Guo, H.Y.; Zhang, H.; Zhu, J.; Ren, F.Z. Partial characterization and immunomodulatory activity of polysaccharides from the stem of Dendrobium officinale (Tiepishihu) in vitro. J. Funct. Foods 2012, 4, 294-301. [CrossRef]

23. Zhang, Z.F.; Lv, G.Y.; He, W.Q.; Shi, L.G.; Pan, H.J.; Fan, L.F. Effects of extraction methods on the antioxidant activities of polysaccharides obtained from Flammulina velutipes. Carbohydr Polym. 2013, 98, 1524-1531. [CrossRef] [PubMed]

24. Thanzami, K.; Malsawmtluangi, C.; Lalhlenmawia, H.; Seelan, T.V.; Palanisamy, S.; Kandasamy, R.; Pachuau, L. Characterization and in vitro antioxidant activity of Albizia stipulata boiv. Gum exudates. Int. J. Biol. Macromol. 2015, 80, 231-239. [CrossRef] [PubMed] 
25. Wu, J.S.; Zheng, J.; Xia, X.J.; Kan, J.Q. Purification and structural identification of polysaccharides from bamboo shoots (Dendrocalamus latiflorus). Int. J. Mol. Sci. 2015, 16, 15560-15577. [CrossRef] [PubMed]

26. Xing, X.H.; Cui, S.W.; Nie, S.P.; Phillips, O.G.; Goff, D.H.; Wang, Q. Study on Dendrobium officinale O-acetyl-glucomannan (dendronan ${ }^{\circledR}$ ): Part I. Extraction, purification, and partial structural characterization. Bioact. Carbohydr. Diet. Fibre 2014, 4, 74-85. [CrossRef]

27. Wang, C.Z.; Zhang, H.Y.; Li, W.J.; Ye, J.Z. Chemical constituents and structural characterization of polysaccharides from four typical bamboo species leaves. Molecules 2015, 20, 4162-4179. [CrossRef] [PubMed]

28. Deng, Y.Y.; Yi, Y.; Zhang, L.F.; Zhang, R.F.; Zhang, Y.; Wei, Z.C.; Tang, X.J.; Zhang, M.W. Immunomodulatory activity and partial characterisation of polysaccharides from momordica charantia. Molecules 2014, 19, 13432-13447. [CrossRef] [PubMed]

29. Fan, Y.J.; Lin, M.C.; Luo, A.S.; Chun, Z.; Luo, A.X. Characterization and antitumor activity of a polysaccharide from Sarcodia ceylonensis. Molecules 2014, 19, 10863-10876. [CrossRef] [PubMed]

30. Xing, X.H.; Cui, S.W.; Nie, S.P.; Phillips, G.O.; Goff, D.H.; Wang, Q. Study on Dendrobium officinale $O$-acetyl-glucomannan $\left(\right.$ dendronan $\left.{ }^{\circledR}\right)$ : Part V. Fractionation and structural heterogeneity of different fractions. Bioact. Carbohydr. Diet. Fibre 2015, 5, 106-115. [CrossRef]

31. Xing, X.H.; Cui, S.W.; Nie, S.; Phillips, G.O.; Goff, H.D.; Wang, Q. Study on Dendrobium officinale O-acetyl-glucomannan (dendronan ${ }^{\circledR}$ ): Part II. Fine structures of $O$-acetylated residues. Carbohydr. Polym. 2015, 117, 422-433. [CrossRef] [PubMed]

32. Hsieh, Y.S.Y.; Chien, C.; Liao, S.K.S.; Liao, S.F.; Hung, W.T.; Yang, W.B.; Lin, C.C.; Cheng, T.J.R.; Chang, C.C.; Fang, J.M.; et al. Structure and bioactivity of the polysaccharides in medicinal plant Dendrobium huoshanense. Bioorg. Med. Chem. 2008, 16, 6054-6068. [CrossRef] [PubMed]

33. Wang, J.H.; Luo, J.P.; Zha, X.Q. Structural features of a pectic polysaccharide from the stems of Dendrobium nobile lindl. Carbohydr. Polym. 2010, 81, 1-7. [CrossRef]

34. Guo, Q.; Cui, S.W.; Wang, Q.; Hu, X.; Kang, J.; Yada, R.Y. Structural characterization of a low-molecular-weight heteropolysaccharide (glucomannan) isolated from Artemisia sphaerocephala krasch. Carbohydr. Res. 2012, 350, 31-39. [CrossRef] [PubMed]

35. Nguyen, T.A.; Do, T.T.; Nguyen, T.D.; Pham, L.D.; Nguyen, V.D. Isolation and characteristics of polysaccharide from Amorphophallus corrugatus in Vietnam. Carbohydr. Polym. 2011, 84, 64-68. [CrossRef]

36. Wang, J.H.; Zha, X.Q.; Luo, J.P.; Yang, X.F. An acetylated galactomannoglucan from the stems of Dendrobium nobile Lindl. Carbohydr. Res. 2010, 345, 1023-1027. [CrossRef] [PubMed]

37. Mosmann, T. Rapid colorimetric assay for cellular growth and survival: Application to proliferation and cytotoxicity assays. J. Immunol. Methods 1983, 65, 55-63. [CrossRef]

38. Schepetkin, I.A.; Quinn, M.T. Botanical polysaccharides: Macrophage immunomodulation and therapeutic potential. Int. Immunopharmacol. 2006, 6, 317-333. [CrossRef] [PubMed]

39. Medzhitov, R.; Janeway, C. Innate immune recognition: Mechanisms and pathways. Immunol. Rev. 2000, 173, 89-97. [CrossRef] [PubMed]

40. Sica, A.; Larghi, P.; Mancino, A.; Rubino, L.; Porta, C.; Totaro, M.G.; Rimoldi, M.; Biswas, S.K.; Allavena, P.; Mantovani, A. Macrophage polarization in tumour progression. Semin. Cancer Biol. 2008, 18, 349-355. [CrossRef] [PubMed]

41. MacKay, R.J.; Russell, S.W. Protein changes associated with stages of activation of mouse macrophages for tumor cell killing. J. Immunol. 1986, 137, 1392-1398. [PubMed]

42. Ali, R.; Kumar, S.; Naqvi, R.A.; Rao, D.N. B and T cell epitope mapping and study the humoral and cell mediated immune response to B-T constructs of YSCF antigen of Yersinia pestis. Comp. Immunol. Microb. 2013, 36, 365-378. [CrossRef] [PubMed]

43. Cerqueira, F.; Cordeiro-Da-Silva, A.; Gaspar-Marques, C.; Simoes, F.; Pinto, M.M.M.; Nascimento, M.S.J. Effect of abietane diterpenes from plectranthus grandidentatus on T- and B-lymphocyte proliferation. Bioorg. Med. Chem. 2004, 12, 217-223. [CrossRef] [PubMed]

44. Jin, Y.; Liu, K.X.; Peng, J.Y.; Wang, C.Y.; Kang, L.; Chang, N.; Sun, H.J. Rhizoma Dioscoreae nipponicae polysaccharides protect HUVECs from $\mathrm{H}_{2} \mathrm{O}_{2}$-induced injury by regulating PPAR $\gamma$ factor and the NADPH oxidase/ROS-NF-кB signal pathway. Toxicol. Lett. 2015, 232, 149-158. [CrossRef] [PubMed]

45. Gille, J.J.P.; Joenje, H. Cell culture models for oxidative stress: Superoxide and hygen peroxide versus normobaric hyperoxia. Mutat. Res. 1992, 275, 405-414. [CrossRef] 
46. Wink, D.A.; Cook, J.A.; Pacelli, R.; DeGraff, W.; Gamson, J.; Liebmann, J.; Krishna, M.C.; Mitchell, J.B. The effect of various nitric oxide-donor agents on hydrogen peroxide-mediated toxicity: A direct correlation between nitric oxide formation and protection. Arch. Biochem. Biophys. 1996, 331, 241-248. [CrossRef] [PubMed]

47. Cantoni, O.; Cattabeni, F.; Stocchi, V.; Meyn, R.E.; Cerutti, P.; Murray, D. Hydrogen peroxide insult in cultured mammalian cells: Relationships between DNA single-strand breakage, poly(ADP-ribose) metabolism and cell killing. BBA-Mol. Cell Res. 1989, 1014, 1-7. [CrossRef]

48. Maeng, O.; Kim, Y.C.; Shin, H.J.; Lee, J.O.; Huh, T.L.; Kang, K.I.; Kim, Y.S.; Paik, S.G.; Lee, H. Cytosolic $\mathrm{NADP}^{+}$-dependent isocitrate dehydrogenase protects macrophages from LPS-induced nitric oxide and reactive oxygen species. Biochem. Biophys. Res. Commun. 2004, 317, 558-564. [CrossRef] [PubMed]

49. Thoeni, G.; Werner, E.R.; Werner-Felmayer, G. Tetrahydropteridines suppress gene expression and induce apoptosis of activated RAW264.7 cells via formation of hydrogen peroxide. Free Radic. Biol Med. 2004, 37, 375-385. [CrossRef] [PubMed]

50. Methacanon, P.; Madla, S.; Kirtikara, K.; Prasitsil, M. Structural elucidation of bioactive fungi-derived polymers. Carbohydr. Polym. 2005, 60, 199-203. [CrossRef]

51. Wang, J.C.; Hu, S.H.; Su, C.H.; Lee, T.M. Antitumor and immunoenhancing activities of polysaccharide from culture broth of Hericium spp. Kaohsiung J. Med. Sci. 2001, 17, 461-467. [PubMed]

52. Wang, Y.F.; Liu, Y.Y.; Mao, F.F.; Liu, Y.R.; Wei, X.L. Purification, characterization and biological activities in vitro of polysaccharides extracted from tea seeds. Int. J. Biol. Macromol. 2013, 62, 508-513. [CrossRef] [PubMed]

53. Zhao, H.; Wang, Q.H.; Sun, Y.P.; Yang, B.Y.; Wang, Z.B.; Chai, G.F.; Guan, Y.Z.; Zhu, W.G.; Shu, Z.P.; Lei, X.; et al. Purification, characterization and immunomodulatory effects of Plantago depressa polysaccharides. Carbohydr. Polym. 2014, 112, 63-72. [CrossRef] [PubMed]

54. Meng, L.; Sun, S.S.; Li, R.; Shen, Z.P.; Wang, P.; Jiang, X.L. Antioxidant activity of polysaccharides produced by Hirsutella sp. and relation with their chemical characteristics. Carbohydr. Polym. 2015, 117, 452-457. [CrossRef] [PubMed]

55. Yang, L.C.; Lu, T.J.; Hsieh, C.C.; Lin, W.C. Characterization and immunomodulatory activity of polysaccharides derived from Dendrobium tosaense. Carbohydr. Polym. 2014, 111, 856-863. [CrossRef] [PubMed]

56. Sevag, M.G.; Lackman, D.B.; Smolens, J. The isolation of the components of streptococcal nucleoproteins in serologically active form. J. Biol. Chem. 1938, 124, 425-436.

57. Zhang, S.S.; Liu, X.Q.; Yan, L.H.; Zhang, Q.W.; Zhu, J.J.; Huang, N.; Wang, Z.M. Chemical compositions and antioxidant activities of polysaccharides from the sporophores and cultured products of Armillaria mellea. Molecules 2015, 20, 5680-5697. [CrossRef] [PubMed]

58. Chen, L.; Liu, J.; Zhang, Y.Q.; Dai, B.N.; An, Y.; Yu, L.L. Structural, thermal, and anti-inflammatory properties of a novel pectic polysaccharide from Alfalfa (Medicago sativa L.) stem. J. Agric. Food Chem. 2015, 63, 3219-3228. [CrossRef] [PubMed]

59. Chen, L.; Xu, W.W.; Lin, S.L.; Cheung, P.C.K. Cell wall structure of mushroom sclerotium (Pleurotus tuber regium): Part 1. Fractionation and characterization of soluble cell wall polysaccharides. Food Hydrocoll. 2014, 36, 189-195. [CrossRef]

60. Green, L.C.; Wagner, D.A.; Glogowski, J.; Skipper, P.L.; Wishnok, J.S.; Tannenbaum, S.R. Analysis of nitrate, nitrite, and $\left[{ }^{15} \mathrm{~N}\right]$ nitrate in biological fluids. Anal. Biochem. 1982, 126, 131-138. [CrossRef]

61. Sun, X.Y.; Liu, N.; Wu, Z.X.; Feng, Y.; Meng, X.J. Anti-tumor activity of a polysaccharide from blueberry. Molecules 2015, 20, 3841-3853. [CrossRef] [PubMed]

62. Iribe, H.; Koga, T. Augmentation of the proliferative response of thymocytes to phytohemagglutinin by the muramyl dipeptide1. Cell. Immunol. 1984, 88, 9-15. [CrossRef]

Sample Availability: Samples of the compounds are not available from the authors.

(C) 2016 by the authors; licensee MDPI, Basel, Switzerland. This article is an open access article distributed under the terms and conditions of the Creative Commons Attribution (CC-BY) license (http://creativecommons.org/licenses/by/4.0/). 